without an acknowledgment of such provision, by means of the broadcasting service, might be permitted. This would be specially useful in the earliest stages of television broadcasting. We are glad that the Committee has recommended that the Empire service should receive express authorisation and should be fostered and developed, and that the appropriate use of languages other than English should be encouraged. In conclusion, the technical investigation of interference with broadcast reception should be expedited, and compulsory limiting powers sought if necessary.

\section{New Northern Ireland Broadcasting Station}

The new Northern Ireland Regional Station of the British Broadcasting Corporation was opened on March 20 by the Duke of Abercorn, Governor of Northern Ireland. This new transmitting station is situated at Lisburn, about nine miles south-west of Belfast. An illustrated technical description of the station given in World Radio of March 20 shows that the design is based upon the experience obtained by the B.B.C. in the erection and operation of the other regional stations. The total power output of the new transmitter is $100 \mathrm{kw}$, and its electrical circuit is very similar in general design to that of the longwave national transmitter at Droitwich. In normal circumstances the power supply for the station is obtained from the system of the Electricity Board for Northern Ireland, which has installed duplicate overhead feeders connected to its 33,000 volt ring main. An emergency supply has, however, been installed, in the form of a 600 horse-power Diesel engine driving a $400 \mathrm{kw}$. three-phase alternator. In addition to the transmitter hall and machine room, the station building contains a control room and office and studio accommodation.

A FEATuRE of great technical interest in the Northern Ireland station is the use of a steel mast about half a wave-length high as the actual aerial, the object of which is to reduce fading as much as possible on the outskirts of the service area. This mast is a cigar-shaped lattice steel structure, 475 feet in height, supported by two sets of stays. The base of the mast rests on a ball-and-socket carried on a heavy plate which is insulated from the concrete foundation by porcelain cylinders. The mast is surmounted by a sliding top-mast, consisting of a steel tube with a horizontal ring at the top. The maximum height of this top-mast is 75 feet, but the electrical length in use has been adjusted to suit the operating wave-length of the station. The aerial tuning circuits are contained in a building at the foot of the mast, and concentric feeders connect these circuits to the output end of the transmitter.

\section{Dr. H. H. Poole: Award of the Boyle Medal}

THE Council of the Royal Dublin Society, on the unanimous recommendation of the Science Committee, decided at its meeting on February 13 to award the Boyle Medal to Dr. H. H. Poole. Dr. Poole, in his capacity as registrar of the Society, has charge of the Society's scientific publications and of its stock of radium, from which originates almost the whole supply of emanation for the Dublin hospitals. The method of preparation is that origin. ally worked out by Joly and since improved by Dr. Poole, a number of whose papers relate to radium therapy. Dr. Poole's first work, beginning in 1910, was done in the geological field under Joly's inspira. tion, and a series of papers was published on the thermal conductivity and specific heat of minerals in their relation to the general question of continental displacement. At a later date, Dr. Poole became interested in the measurement of daylight, charac. teristically because his colleagues in the biological field required help. He has now made the subject of photo-electric cells and light measurement pecu. liarly his own, and the practical application to the measurement of diurnal and season variation in daylight and the penetration of light waves into woods and especially into the sea have been valuable. The stream of work on this subject is still in full progress, and a total of some twenty-eight papers have appeared in the last ten years, many in col. laboration with Dr. W. R. G. Atkins, of the Marine Biological Laboratory, Plymouth.

\section{American Flood Devastation}

Every now and again, Nature seems to take an impish delight in playing havoc with man's efforts to control her vagaries, flinging aside his puny re straints and sweeping both him and his works into a common destruction. One of her most potent agencies is water, and the catastrophic visitation which, following sudden heavy rains and melting snows, descended on fourteen highly industrialised and commercial States in the eastern part of the North American continent during the past week or ten days is the latest example of her indiscriminate violence. On March 18, with little or no warning, the Pennsylvanian towns of Johnstown and Pitts. burgh, notable centres of the steelwork industry, found their streets submerged to depths of 10-15 ft., and in places considerably more, so that the unfortunate inhabitants were speedily reduced to dire straits from shortage of food and drinking water. Many were compelled to spend a night of terror perched on the roofs of their houses, scantily clothed, while a number of them, approaching one hundred, regrettably lost their lives in the darkness and con. fusion. Johnstown was the scene of a terrible disaster in May 1889, when a reservoir above the city collapsed, causing the loss of 3,000 lives. Pitts. burgh, too, had a serious flood in 1913. On the present occasion, the estimates of damage to pro. perty run to 40 million pounds sterling at Pittsburgh and to 7 millions at Johnstown, at which latter place some 8,000 persons are said to be homeless. The whole countryside, in fact, in eastern Pennsylvania has been more or less under water.

Practically simultaneously, the rivers in all the New England States, with those in New York, New Jersey, Delaware, Maryland, Virginia, West Virginis 